\title{
Determinant Factors Poverty of Relativity in Banten Province: A Panel Data Analysis
}

\author{
Deris Desmawan 1)*, Rizal Syaifudin ${ }^{2)}$, Randi Mamola ${ }^{3)}$, Hanifa Haya ${ }^{4)}$, Dwi Indriyani ${ }^{5)}$ \\ 12)344)5) Economics and Development Study, Faculty Of Economics and Business, Universitas Sultan \\ Ageng Tirtayasa, Serang City, Indonesia \\ *E-mail corresponding author: derisdesmawan@gmail.com
}

Received: 30-08-2021;

Accepted: 23-10-2021;

Available online: 31-10-2021

\section{Ecoplan}

Vol. 4 No. 2, Oktober 2021, hlm 131-141

\section{ISSN p: 2620-6102 e: 2615-5575}

\begin{abstract}
Abstrak - Masalah relativitas kemiskinan saat ini masih menjadi topik yang krusial mengingat kondisi ekonomi di Indonesia sedang mengalami keterpurukan akibat Covid-19. Masalah relativitas kemiskinan menjadi salah satu poin utama yang harus dihadapi pemerintah dalam memberikan kebijakan bantuan perlindungan sosial sebagai bentuk pemulihan ekonomi di masa Covid-19. Relativitas kemiskinan di Provinsi Banten relatif tinggi meskipun telah menduduki peringkat 10 secara nasional. Oleh karena itu, penelitian ini bertujuan untuk menganalisis hubungan antara pengangguran, ketimpangan pendapatan, dan sumber daya manusia serta mengetahui tingkat mana yang sangat dominan dalam jangka panjang pada masing-masing variabel yang secara langsung mempengaruhi relativitas kemiskinan di Provinsi Banten. Penelitian ini mengkaji bagaimana terjadinya perubahan indikator ekonomi akibat pandemi Covid-19 di 8 Kabupaten/Kota di Provinsi Banten. Analisis penelitian ini menggunakan regresi data panel menggunakan metode Fixed Effect Model (FEM) di 8 kabupaten/kota di Provinsi Banten pada rentang data tahun 2016 sampai dengan tahun 2020. Hasil penelitian ini menunjukkan bahwa pengangguran akibat PHK memiliki pengaruh positif dan berpengaruh signifikan terhadap relativitas kemiskinan di 8 kabupaten/kota di Provinsi Banten. Selanjutnya, penelitian ini menunjukkan bahwa ketimpangan pendapatan tidak berpengaruh signifikan dan positif terhadap relativitas kemiskinan. Sementara itu,
\end{abstract}

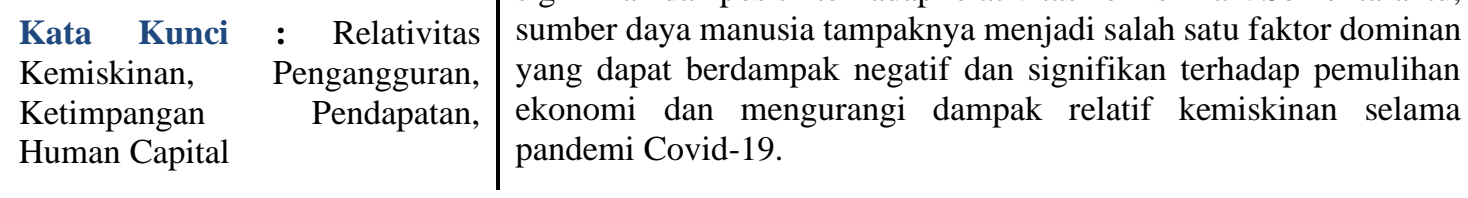

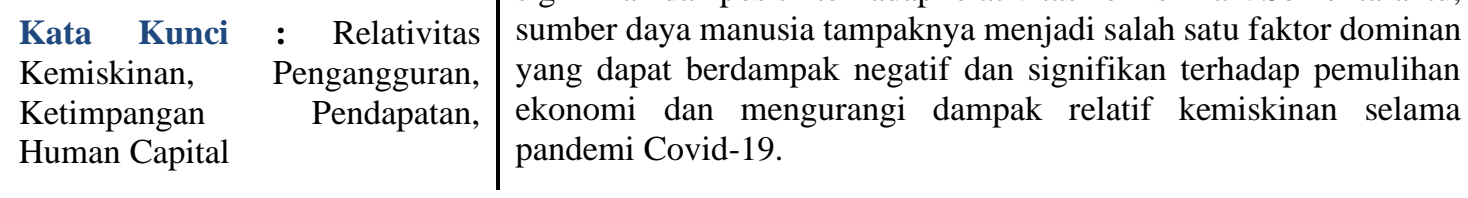

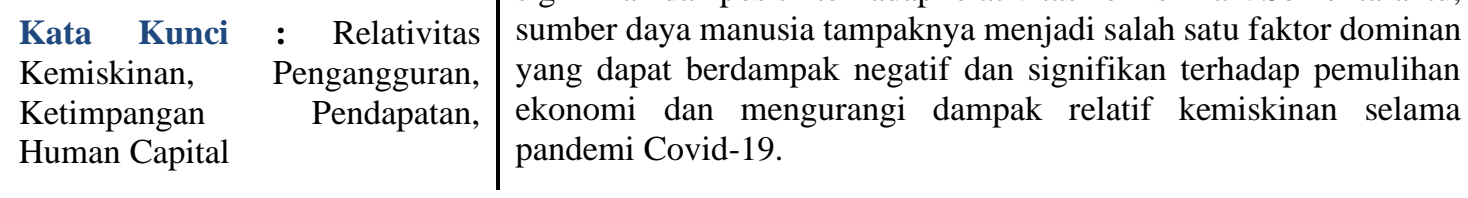

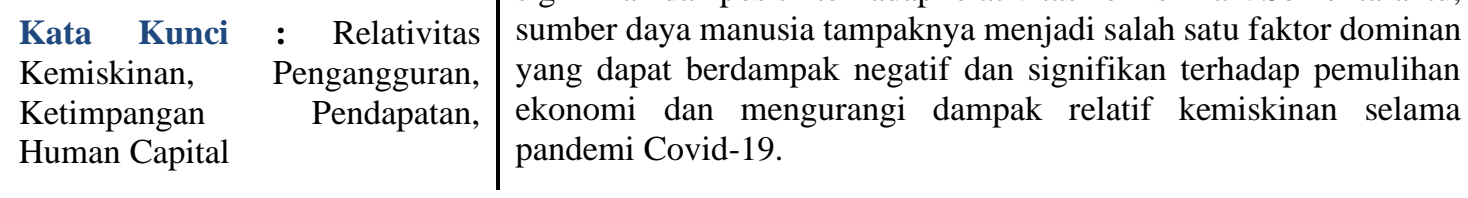

Abstract - The poverty of relativity today is still a crucial topic considering the economic conditions in Indonesia are experiencing a slump due to Covid-19. The problem of poverty relativity is one of the main points that the government must face in providing social protection assistance policies as a form of economic recovery during the Covid-19. The poverty of relativity in Banten Province is relatively high even though it has been ranked ten nationally. Therefore, this study aims to analyze the relationship between unemployment, income inequality, and human capital and find out which level is very dominant in the long run on each of the variables that directly affect the relativity of poverty in Banten Province. This study examines how economic indicators change due to the Covid-19 pandemic in 8 Regencies/Cities of Banten Province. The analysis of this study uses panel data regression using the method Fixed Effect Model (FEM) in 8 regencies/cities in Banten Province in the data range from 2016 to 2020. This study indicates that unemployment due to layoffs has a positive and significant influence on the relativity of poverty in 8 districts/cities of Banten Province. Furthermore, this study shows that income inequality has no significant and positive effect on the relativity of poverty. Meanwhile, human capital appears to be one of the dominant factors that can have a negative and significant impact on economic recovery and reduce the relative impact of poverty during the Covid-19 pandemic.

Keywords: Poverty of Relativity, Unemployment, Income Inequality, Human Capital 


\section{INTRODUCTION}

A developed country is a country whose economy is developing very rapidly. On the other hand, developing countries are still in the process of recovering their economic conditions. Development problems are very widespread and have also become the main focus that must be addressed by several developing countries (Susanti, 2013). The purpose of establishing a country, in general, is to provide welfare for the entire community or population in a country (Ngozi et.al., 2020). However, this is not the case with the state in Indonesia, which is still involved in problems in fulfilling the welfare of its people, both in the fields of education and health. This will be the basic focus of development problems that often occur in Indonesia, namely the problem of the relativity of poverty.

The problem of relativity to poverty in Indonesia is not a problem that appears for the first time but has spread since the pre-reformation period until now (Megawati \& Br. Sebayang 2018). This makes the emergence of the relativity of poverty in Indonesia the most significant and dominant form of problems faced by current government policies. All policies and programs established by the government are carried out to alleviate poverty in the Province of Indonesia. The relativity of poverty has always been identified as a major problem in developing countries because maximizing people's welfare has not been achieved (Safuridar \& Putri, 2019). Indonesia, which is 64 years old, has not been able to get out of the relativity of the poverty trap, even though Indonesia has experienced significant economic development.

Starting in early 2020, the problem of increasing relativity of poverty has hit Indonesia again. The increasing relativity of poverty that is currently happening in an issue or trending topic that must be investigated considering the outbreak of the pandemic Covid-19 throughout the world. The outbreak of Covid-19 had a bad impact on public health and had a significant impact on economic growth in the world, including the economy in Indonesia. But ironically, the country of Indonesia is currently experiencing a recession due to the outbreak of Covid-19 which has hampered the economic system. The impact of Covid19 seems to have begun to be seen in the portrait of the relativity of poverty which also increased from 0.56 percent in 2019 to 9.78 percent in 2020 (BPS, 2020). When viewed from its development, poverty in Indonesia shows that household consumption expenditure is getting worse due to the high unemployment rate due to large-scale social restrictions.

On the other hand, the impact of the problem Covid-19 also greatly affects economic aspects in each region, including the area affected by the red zone, namely Banten Province. The increase in the poverty rate in Banten Province also experienced a spike from 4 percent to 5.03 percent in March 2020 (BPS, 2020). The soaring number of poor people in Banten Province is caused by the high unemployment rate, which is also increasing. The relativity of poverty in the Banten Province is also caused by other factors such as the high level of income inequality. The problem of income inequality and poverty is an inseparable part of the central factor inhibiting the rate of economic growth (Wijayanto, 2016). In addition, income inequality or disparity that occurs in Banten Province is currently experiencing a decline even though, in reality, income inequality only occurs in urban areas due to the outbreak of Covid-19.

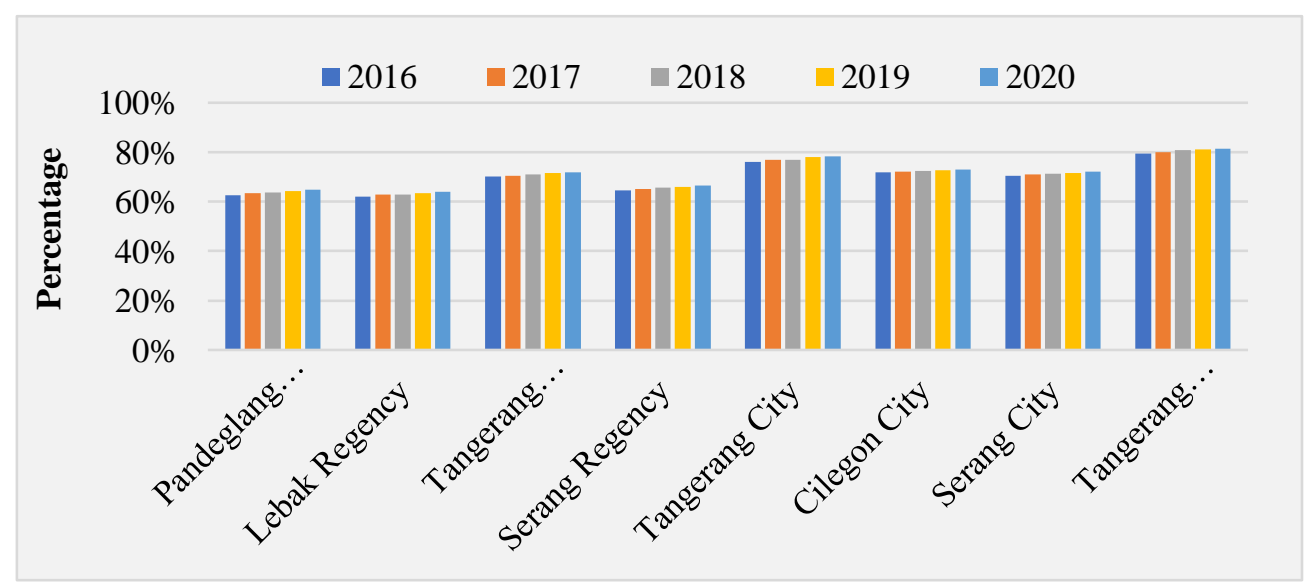

Figure 1. Comparison Poverty of Relativity in 8 Districts/Cities Banten Province Source: BPS Banten Province, 2020 (data prepared)

Figure 1 shows the development of poverty relativity in Banten Province in each of the eight districts/cities that experienced an increase in 2020. Based on this figure, it can be seen that several areas in Banten Province experienced an increase in poverty relativity as a result of the impact of Covid-19 which 
resulted in the economy slumping. Although the availability of government assistance or subsidies programs can reduce the problem of poverty relativity in Banten Province, it is carried out continuously to improve economic performance. However, this condition is not possible due to a worsening social phenomenon, marked by the emergence of various problem factors such as the high number of layoffs or unemployment due to the Covid-19 pandemic. Of course, this will increase the scope of the economy in Banten Province, which needs to be improved considering that Banten Province currently ranks 2nd with the highest unemployment rate in Java.

Several factors affect the relative level of poverty. In poor countries, the relativity of poverty can be improved through a combination of four elements to achieve development goals (Todaro, 2006). The four elements are none other than labor, capital, resources, and innovation (Olopade et al., 2019). The concept of relativity of poverty also arises from problems in the use of resources that are not optimal, and this happens because it is caused by three things, namely the limited level of education, low skills and skills, and limited production mobility (Fikri, 2017).

Several theories that explain the New Growth theory strongly emphasize the importance of the government's role in increasing human resource development through increasing access to education and health. The high quality of human capital development will encourage community productivity which will be very useful for reducing the relativity of poverty in Banten (Sayifullah \& Gandasari 2016).

Therefore, this study aims to determine the impact of the outbreak of Covid-19 on the relativity of poverty in Banten Province and the dominant factors that influence it. The urgency of this research lies in three aspects. First, this study will discuss the results of research that are different from previous studies regarding the dominant factors that affect the relativity of poverty. Second, the economic condition in Indonesia, especially in Banten Province, is experiencing a recession due to the impact of the Covid-19 outbreak. Third, this study focuses on relativity poverty in Banten Province which has increased.

\section{Previous Research}

Susanti (2013) examined the Effect of Gross Regional Domestic Product, Unemployment and Human Development Index on Poverty in West Java using Panel Data Analysis and the results showed that GRDP partially affected poverty positively and significantly, unemployment partially affected poverty partially positive and significant and the HDI partially has a significant negative effect on poverty.

Prasetyoningrum (2018) examines the Analysis of the Effect of the Human Development Index (HDI), Economic Growth, and Unemployment on Poverty in Indonesia using panel data regression analysis. His research shows that HDI has a direct and negative effect on the level of poverty and economic growth has no significant effect on reducing the level of poverty.

Mukthar, Saptono \& Arifin (2019) examines the Analysis of the Effect of the Human Development Index (HDI) and the Open Unemployment Rate on Poverty in Indonesia. By using panel data regression analysis. The results showed that the human development index (HDI) had a negative and significant effect on poverty. Meanwhile, the open unemployment rate is positive and not significant to the poverty level.

Putra \& Arka (2016) examined the Analysis of the Effect of Open Unemployment Rates, Job Opportunities, and Education Levels on Poverty Levels in Regencies/Cities in Bali Province. By using multiple linear regression analysis. The results of the research are that the open unemployment rate has a positive and significant effect on the poverty level, employment opportunities have a negative and significant effect on the poverty level, and the level of education has a negative and significant effect on the poverty level.

Yacoub (2012) conducted a study entitled The Effect of Unemployment Rate on Poverty Levels in Districts/Cities in West Kalimantan Province. The method in this research is panel data regression. The results of this study are the unemployment rate has a significant effect on the poverty level of districts/cities in West Kalimantan Province.

Kiaušienè (2015) researched poverty entitled Comparative assessment of women unemployment and poverty in the European Union. The locations in this study were 28 countries in Europe. The method used in this research is correlation-regression analysis, min-max index, and mean index. This study has the result that the female unemployment rate increases, so women are at risk of experiencing a decrease in poverty.

Mardiyana \& Ani (2019) researched education and unemployment with the title The Effect of Education and Unemployment on Poverty in East Java Province 2011-2016. The location of this research is on the island of Java, Indonesia. The research method used is panel data regression. This study indicates that education has a positive and significant effect on poverty, then unemployment has a negative and significant effect on poverty. 
Widodo et.al, (2019) researched poverty with the title Panel Regression Analysis on Poverty Cases in Indonesia. The method used is panel data regression. This study shows that HDI results have a significant and positive effect on poverty, income inequality has a significant effect on poverty and gross enrollment rate has a significant effect on poverty.

Saddam et.al, (2019) conducted a study entitled Analysis of Poverty in Eastern Indonesia. The method used is panel data regression. The results of this study are economic growth has a significant effect on poverty, income inequality has a significant effect on poverty, unemployment has a significant effect on poverty, education has a significant effect on poverty and health has a significant effect on poverty.

Chemli \& Smida (2013) researched the Interaction Between Poverty, Growth, and Inequality during the Crisis: A Panel Data Study. The research locations are Algeria, Egypt, Iran, Jordan, Morocco, Tunisia, Syria, and Yemen. The method used in this research is panel data regression. This study shows that GDP has a positive effect on poverty, income inequality has a positive effect on poverty, a crisis has a negative effect on poverty, inflation has a negative effect on poverty, open market operations have a negative effect on poverty, the rural population has a negative effect on poverty, infrastructure has a negative effect on poverty and government spending on education has a negative effect on poverty.

Adeleye et al. (2020) conducted a study entitled Comparative investigation of the growth-povertyinequality trilemma in Sub-Saharan Africa and Latin American and Caribbean Countries. The location of this research is Sub-Saharian Africa, Latin America, and Caribbean Countries. This research uses panel data regression and the GMM method. The results show that economic growth has a significant effect on poverty, income per capita affects poverty, income inequality has an effect on poverty, education has an effect on poverty, and unemployment has an effect on poverty.

Nisa et.al, (2020) conducted a study entitled The Effect of Income Inequality on Poverty in the Province of the Bangka Belitung Islands in 2009-2018. This study uses simple linear regression. The results of this study indicate that income inequality has a negative and significant effect on poverty.

Olopade et.al, (2019) conducted a study entitled Human Capital and Poverty reduction in OPEC Member Countries. The location of this research is 12 member countries of OPEC. This research uses the panel data regression method. The results showed that education had a positive effect on poverty and health positively affected poverty.

Meo et.al, (2020) conducted a study entitled Impact of Unemployment and Governance on Poverty in Pakistan: a Fresh Insight from Non-linear ARDL Co-integration Approach. Locations studied by the state of Pakistan. This study uses the AEDL Co Integration method. The results of this study are unemployment has a positive and significant effect on poverty and the government has a significant negative effect on poverty.

Mohammad \& David (2019) researched the Relationship between Poverty and Unemployment in Niger State. The location of this research in Nigeria. The method used is descriptive statistics and logistic regression models. The results showed that unemployment affected poverty, education affected poverty and household income affected poverty.

\section{LITERATUR REVIEW AND HYPOTHESIS DEVELOPMENT}

Theory Poverty of Relativity

A study by Mukthar, Saptono \& Arifin (2019), the concept of relativity of poverty has become a separate reference and is a problem that cannot be solved because it involves the condition of someone who is said to be unable. The phenomenon of poverty has often been encountered in the lives of some people, even this problem has often appeared in remote areas. Poverty is also often said to be a multidimensional problem that is more a symptom of low welfare in a person's life (Kuswantoro \& Dewi, 2016). The government has carried out various ways through assistance or subsidies programs to reduce the relativity of poverty, but according to statistical data, the relativity of poverty is increasing and in line with the problem of increasing the growth of the poor population. Various sources of theories explain the relativity of poverty, namely there are two theories (grand theory) that underlie the theory of poverty, namely the Neo-Liberal theory and the Social-Democratic theory. These two theoretical paradigms are closely related to policy analysis and the formulation of poverty reduction relativity (Kuswantoro \& Dewi 2016).

\section{Neo-Liberal Theory}

According to experts who analyzed poverty, Shannon, Spicker, Cheyne, O'Brien, and Belgrave concluded that the poverty rate will decrease if economic growth can be increased (Syahyuti, 2006). These economists have answered that poverty is a residual or interrelated problem. The role of the government is indispensable if the problem of poverty cannot be overcome. Therefore, the government has a policy program to reduce 
poverty in an area, such as the provision of social assistance provided by the government to the poor (Kuswantoro \& Dewi, 2016).

\section{Social Democracy Theory}

This theory differs from the previous theory which views poverty as a temporary problem because it involves several individuals. The opinion of this theory is that poverty is focused on structural properties (Christine, O'Brien and Belgrave, 1998). The basic concept of this theory is that poverty is caused by inequality or inequality caused by obstructed access to public services, so this theory emphasizes government spending to provide access to social services for the people for the welfare of the people (Kuswantoro \& Dewi, 2016).

\section{Unemployment}

Unemployment is one form of macro problem, meaning that unemployment has a significant and direct influence on the economic system, so it is too difficult to overcome because it involves a person's standard of living. While technically unemployment is defined as someone who enters the age of the labor force who does not work even though his status is already working independently and earning wages, then he will look for another job to fulfill his next life needs (Erfani, 2019). The unemployment rate is closely related to the low quality of human resources resulting in a person's capital accumulation will also be reduced. Therefore, the education sector plays an important role in controlling human resources in the community and increasing the need for employment according to educational qualifications and individual skills (Safuridar and Putri, 2019).

\section{Income Inequality}

The condition of income inequality is the most crucial aspect of the poverty level. The increase in the number of poor people in society will not decrease if they still have limited access and low per capita expenditure (Omar \& Inaba, 2020). Income inequality is also influenced by development, ethnic or ethnic differences, and is also related to the government's failure to distribute income evenly according to certain categories (Wijayanto, 2016). Based on Todaro and Smith (2008), explaining the impact of income inequality in society will bring several negative impacts from an economic and social perspective, namely:

a). Income inequality will have a negative impact on the economy.

b). Income inequality will weaken social stability and solidarity.

c). Income inequality will also have an impact that causes a high level of crime.

\section{Human Capital}

The concept of human capital has existed since the emergence of hypotheses in the analysis of economics, even the theory is often used as an indicator to measure the success of development in an area. According to Todaro and Smith (2008), human capital is identified as human resources where human capital is a form of skills, abilities, aspirations, health and so on which are part of the level of community welfare. Human resources will be achieved optimally if the government can increase the level of spending in education and health. Quality education and health can ensure that every community has adequate qualifications and can also be used as a benchmark for government policies to reduce poverty in an area (Olopade et.al., 2019). In line with this description, four paths of human capital can affect poverty alleviation, namely:

a. Human capital can create a productive investment system.

b. Human capital produces superior human resources and this can avoid income inequality in society.

c. Human capital can break the cycle of poverty in society.

\section{Research Hypothesis}

The phenomenon of the relativity of poverty in Banten Province is a crucial problem that must be overcome. The current Covid-19 pandemic outbreak has caused a complicated discussion regarding how the government's policy steps are to improve the national economy. Based on the supporting theory and previous research, the researcher formulated a framework of thinking on the factors that dominate the relativity of poverty in Banten Province. Based on previous research that has been discussed previously, this study has the following hypothesis:

H1: An increase unemployment rate will give a positive impact on the relativity of poverty.

H2: An increase income inequality will give a positive impact on the relativity of poverty.

H3: An increase human capital will give a negative influence on the relativity of poverty. 


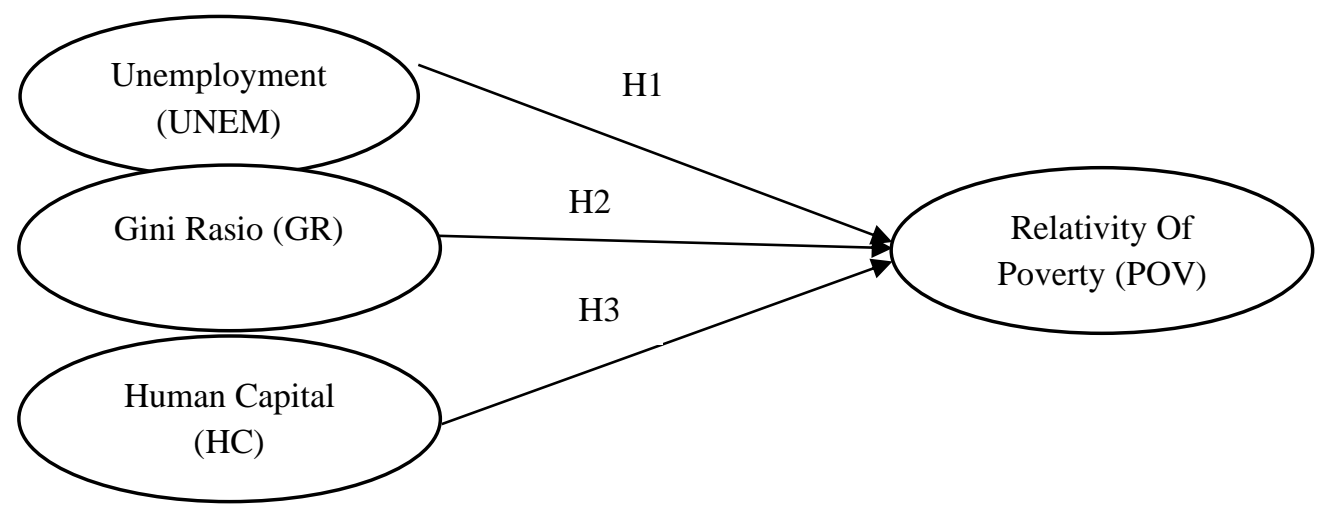

Figure 2. Research Framework and Hypothesis Development

\section{RESEARCH METHOD}

The Scope of Research

Objects that become the scope of this research include; relativity of poverty which is the percentage level of the average number of poor people in 8 districs/cities of Banten Province; the unemployment rate which is defined as the average percentage of the population who do not have a job and are looking for work; income inequality/Gini ratio using the Gini index measure; and human capital which includes the percentage of the human development index as measured by indicators of education and human health degrees. The range of data used in this study is from the period 2016 to 2020.

Collection Technique and Data Analysis

The source of data taken in this study is secondary data from the Central Statistics Agency (BPS) of Banten Province. This type of research data is quantitative, the data collected is in the form of reports/publications of relevant agencies that will be tested based on a series of rules of economic analysis (Hussein, 2004). The data to be processed or analyzed uses panel data analysis techniques, a combination of cross-section and time-series (Gujarati \& Porter, 2015). The analytical tool used to analyze panel data regression is using eviews 8.0 software using the Fixed Effect Model (FEM) method. The model used in this analysis is as follows:

$\mathrm{POV}_{\mathrm{it}}=\beta_{0}+\beta_{1} \mathrm{UNEM}_{\mathrm{it}}+\beta_{2} \mathrm{GR}_{\mathrm{it}}+\beta_{3} \mathrm{HC}_{\mathrm{it}}+\varepsilon_{\mathrm{it}}$

Explanation :

\begin{tabular}{|c|c|}
\hline $\mathrm{V}$ & $=$ Relativity of Poverty (Percent) \\
\hline UNEM & $=$ Unemployment $($ Percent $)$ \\
\hline GR & $=$ Income Inequality/Gini Rasio (Index) \\
\hline $\mathrm{HC}$ & = Human Capital $($ Index $)$ \\
\hline$\beta_{0}$ & $=$ Interception, $\mathrm{Y}$ value when $\mathrm{X}=0$ (constant price) \\
\hline$\beta_{1}, \beta_{2}$, and $\beta_{3}$ & $\begin{array}{l}=\text { Regression coefficients of each independent variable; } \\
=\text { Error }\end{array}$ \\
\hline & $\begin{array}{l}=\text { Observations (cross-section) } \\
=\text { Time }\end{array}$ \\
\hline
\end{tabular}

\section{RESULTS AND DISCUSSION}

\section{Model Selection}

The research method used in selecting the best model estimation in panel data analysis, the technique used to process panel data has three approaches, namely Common Effect Model (CEM), Fixed Effect Model (FEM), and Random Effect Model (REM) (Gujarati \& Porter, 2015). CEM assumes that the behavior of corporate data is same in various periods. FEM assumes that there is a correlation between an entity's error term and independent variables, and the time-variant characteristics are unique to the individual and should not be correlated with other individual characteristics. REM assumes that individual components are not 
correlated with each other and are not auto-correlated across both cross-section and time series (Gujarati \& Porter, 2015).

The results of processing the estimation data from the independent variable to the dependent variable in this study used the estimation of the FEM model. The first step to test the panel data model stages is to perform the Chow test which is used to determine whether the selected model is the FEM or CEM model. The results of the Chow test criteria can be seen in Table 1, as follows:

$\mathrm{H}_{0}: \rho_{\text {value }}>\alpha$ Common Effect Model.

$\mathrm{H}_{1}: \rho_{\text {value }}<\alpha$ Fixed Effect Model.

1. Chow Test

Table 1. The Result of The Chow Test

\begin{tabular}{lccc} 
Effect Test & Statistic & d.f & Prob. \\
\hline Cross-Section F & 170,634249 & $(7,29)$ & $0,0000^{* *}$ \\
\hline $\begin{array}{l}\text { Cross-Section Chi- } \\
\text { Square }\end{array}$ & 149,685032 & 7 & $0,0000^{* *}$ \\
\hline
\end{tabular}

Source: Eviews 8.0 (Data Processed)

Note: *** Significant 1\%, ** Significant 5\%, * Significant $10 \%$ based on the t- statistical level.

The criteria for specific test results in the Chow test (table 2) show that the probability of Chi-Square $<0,05$ or $0.0000<\alpha(\alpha=0.05)$, which means that the model chosen to continue the research model of panel data estimation is a model Fixed Effect Model (FEM). After testing the Chow test, the next step is to test the estimation of the Hausman test. The Hausman test was conducted to compare the FEM and REM models in selecting the best model for panel data research processing (Widarjono, 2007). The Hausman test results in several criteria, as follows:

$\mathrm{H}_{0}: \rho_{\text {value }}>\alpha$ Random Effect Model.

$\mathrm{H}_{1}: \rho_{\text {value }}<\alpha$ Fixed Effect Model.

2. Hausman Test

Table 2. The Result of The Hausman Test

\begin{tabular}{lccc}
\hline \multicolumn{1}{c}{ Test Summary } & Chi.Sq.Stat & Chi.Sq.d.f & Prob. \\
\hline Cross-Section & 35,553575 & 3 & $0,0000^{* *}$ \\
Random & & & \\
\hline ource: Eviews 8.0 (Data Processed) & & &
\end{tabular}

Note: $* * *$ Significant $1 \%$, ** Significant $5 \%$, * Significant $10 \%$ based on the t- statistical level.

Based on the test results Hausman test (Table 2), a result that the probability of a random crosssection $<(0.05)$ or $0.0000<\alpha(\alpha=0.05)$, which means that the model chosen to continue the estimation of this panel data research model is the Fixed Effect Model (FEM) model. Therefore, the results of testing the panel data regression research variables using the FEM (Fixed Effect Model) method. While the variables used are the relativity of poverty, unemployment, income inequality, and Human Capital. The results of the best model testing with a significance level of $0.05 \%$ in the Chow test and Hausman test are the estimation steps for selecting the model used to continue the panel data research in 8 Districts/Cities of Banten Province.

According to the panel data model estimation, the correlation between the variables in this study uses a Fixed Effect Model (FEM) approach with generalized least square (cross-section weights) method. Then the relationship between these variables can be interpreted into the estimation results in table 3 , as follows: 
Table 3. The Estimation Results of The Selected Model

\begin{tabular}{lcrrl} 
Variables & Coefficient & Std. Error & t-statistic & Prob. \\
\hline C & $-4,587074$ & 4,204600 & $-1,090966$ & 0,2843 \\
UNEM & 0,158613 & 4,204600 & 5.400106 & $0,0000^{* *}$ \\
GR & 0,686636 & 1,141577 & 0,601480 & $0,5522^{* *}$ \\
HC & $-0,118703$ & 0,057065 & $-2,080142$ & $-0,0465^{* *}$ \\
\hline R-Squared & 0,993802 & & & \\
F-Statistic & 464,9859 & & & \\
Prob-F & $0,000000 * *$ & & & \\
\hline
\end{tabular}

Source: Eviews 8.0 (Data Processed)

Note: *** Significant 1\%,** Significant 5\%, * Significant $10 \%$ based on the t- statistical and fstatistical level.

The estimation results in the table above, the panel data regression equation can be formed in the following formulation:

$\mathrm{POV}_{\text {it }}=-4,587074+0,158613 \mathrm{UNEM}_{\mathrm{it}}+0,686636 \mathrm{GR}_{\mathrm{it}}-0,118703 \mathrm{HC}_{\mathrm{it}}+\varepsilon_{\mathrm{it}} \ldots(2)$

Based on Table 3, it is known that the panel regression model testing using the Fixed Effect Model (FEM) concluded that the unemployment variable has a positive effect (coefficient value of 0.158613), Gini ratio has no effect and was positive (coefficient value of 0.686636), and human capital has a negative effect (coefficient value of 0.118703 ) on the relativity of poverty in 8 districts/cities in Banten Province. The constant value in the regression estimation in 8 districts/cities of Banten Province has a value of -4.587074 , meaning that this value explains if the value of the unemployment variable (UNEM), Gini ratio (GR), and human capital (HC) is 0 (zero)., it shows that the Poverty Relativity (POV) variable in 8 districts/cities of Banten Province has an average value of -4.587074 percent.

\section{Discussion}

The first hypothesis proposed in this research is that the unemployment rate positively affects the relativity of poverty. The estimation results in this study indicate that the unemployment rate variable has a positive and significant influence on the relativity of poverty in 8 regencies/cities of Banten Province with a tstatistic $>$ t-table $(5.40>2.02)$ and a probability value of $0.000(<0.05)$, so that $\mathrm{H}_{0}$ is rejected. The high unemployment rate of 1 percent will cause an increase in poverty relativity by 0.16 percent and the regression results that have been obtained show significant. The regression results can be concluded that this analysis agrees with the research conducted by (Mohammad Bintang and Woyanti, 2018) which explains that the low absorption of labor due to limited production activities can lead to high unemployment which can result in low community productivity which has a direct impact on social problems such as relativity of poverty. Limited job opportunities will hamper the overall productivity of the economy and the income of the population will decrease which will later lead to poverty problems in an area (Arsyad, 2010). Until now, the problem of unemployment in Banten Province has not been resolved because there is still a lack of jobs that meet the qualifications of one's expertise. The existence of physical capital in the form of skills or skills possessed by a person can break the chain of unemployment rates, where a person's skills or skills can grow productivity and qualifications while in the world of work (Sukirno, 2011). Layoffs that occur on a large scale have a negative impact on the level of community productivity. People who are already unemployed will find it difficult to find work again because of the difficulty of accessing community movements due to social restrictions policies during the Covid-19 pandemic. Given that Banten Province is the province with the highest unemployment rate in Java, it is clear that the high unemployment rate has a relationship and is the dominant factor causing poverty due to the decline in people's purchasing power (Sayifullah \& Gandasari, 2016).

The second hypothesis in this study, the variable income inequality, positively impacts the relativity of poverty. The estimation results of the income inequality variable show that the value of the variable partially has a positive and insignificant effect on the relativity of poverty in 8 districts/cities of Banten Province with a t-statistic < t-table $(0.60<2.02)$ and a probability value of $0.552(>0.05)$, so that $\mathrm{H}_{0}$ is accepted. This means that income inequality, which has increased by 1 percent, will increase the relativity of poverty by 0.69 percent with no significant results. These results prove that the relationship on the effect of income inequality on poverty is in line with research conducted by (Wijayanto, 2016) which shows the variable income inequality has a positive and insignificant effect on the high relativity of poverty. The high- 
income inequality in the Regencies/Cities will be the main cause of the high relativity of poverty in Banten Province. This happens because of the rapid development in several regions, leading to increased development that is still focused on centralization or only sees developments on regional advantages (Sumiyarti, 2019). If viewed from the structure of the economy in the Regencis/Cities in Banten Province, the area that tends to have the largest contribution to its sector, then the area has an increasingly rapid growth rate. Regions with faster-growing economic sectors will have more opportunities to have an equitable development process and of course supported by increased incomes that can reduce the relativity of poverty (Ngozi et.al., 2020). Unlike the case with areas that have not or are still developing, the economic structure of this sector usually still relies on agricultural and livestock activities. So that the distribution of income between developed and developing regions will be more unequal. Centralized development often triggers problems of economic inequality in other areas.

Furthermore, the last hypothesis formulated in this research is that human capital has a negative effect on the relativity of poverty. The estimation results of the variable human capital show a regression value that has a negative and significant effect on the relativity of poverty in 8 regencies/cities of Banten Province which has a t-statistic $>t$-table $(-2.08>-2.02)$ and the probability value is $-0.046(<0.05)$, so that $\mathrm{H}_{0}$ is rejected. If there is an increase in human capital as seen from the education and health indicators by 1 percent, it can reduce the relativity of poverty by 0.19 percent. The theory of human capital shows that a person will be more productive if the length of time taking education is maximum and can estimate the individual's economy (in the form of income) from the education one gets (Sadariawati, 2017). The basic assumption of theory human capital can be proven that a person can have a high level of income through increased education and health. The level of community welfare will increase, preventing a person from entering the abyss of poverty (Mukthar, et.al, 2019). According to research (Olopade, et.al., 2019), high human capital can guarantee a person's degree to be able to live in prosperity. This is because government subsidies to improve education and health are indicated to affect a person's index value directly. Therefore, indications of subsidized assistance for education and good health are certainly very useful to provide a decent life for the community. Limited access to education and inadequate health will result in the high relativity of poverty in the community. So that the community also has a low level of productivity and cannot meet the needs of a decent life.

\section{CONCLUSION}

This study indicates that unemployment has a positive and significant effect on the relativity of poverty in society. Until now, the problem of unemployment in Banten Province remains a key factor that can contribute to the high level of relativity poverty. Interestingly, income inequality in Banten Province has a different path with its effect on the relativity of poverty. This study provides contradictory results regarding poverty alleviation through income distribution. The results of data analysis show that income inequality is not significant and has a positive value on the relativity of poverty because differences strongly influence this in the conditions of regional development centers that are growing rapidly and have potentials diverse in 8 districts/cities of Banten Province. In addition, one of the determinants of poverty alleviation relativity in Banten province is improving human resources through support access to education and health degree. According to the research results, human capital is the dominant factor because it has a negative and significant impact on reducing the relative poverty in 8 districts/cities of Banten Province.

In the explanation of the conclusions of this study, it can formulate beard being how recommendation research results. First, the government needs to increase the budget by channeling direct assistance to the poor, such as social assistance and cash and non-cash assistance. Through direct assistance to the community, the recovery of economic conditions due to Covid-19 can be handled properly. Second, the government's efforts must also provide social assistance for people affected by Covid-19, especially for workers who have lost their jobs by increasing workshops or subsidizing worker funds so that those who are unemployed can return to work. Third, development authority in important sectors needs to focus on increasing income distribution accompanied by the high quality of natural and human resources. Fourth, to restore the national economy and reduce the relativity of poverty, the government needs to provide quality education and health facilities. In addition, assistance that is directly related to the provision of education and health subsidies to the underprivileged can be used as a government policy to provide opportunities for the community to improve the formation of human resources.

\section{REFERENCES}

Arsyad, L (2010), Ekonomi Pembanguan (Edisi Kelima)', Yogyakarta: UPP STIM YKPN.

Chemli, L, \& Smida, M (2013), 'Interaction between Poverty, Growth, and Inequality during the Crisis: A Panel Data Study', International Journal of Economics and Finance, 5(5). doi: 
10.5539/ijef.v5n5p120.

Christine, C., O’Brien, M, \& Belgrave, M (1998), Social Policy In Aotearoa New Nealand: A Critical Instroduction. Auckland: Oxford University.

Erfani, M, H (2019), 'Analysis Of The Effect Of Economic Growth, Per Capita Income And Working For Against Absolute Poverty Level In Hulu Sungai Utara District', Jurnal Ecoplan, 2(1), pp. 1-9.

Fikri, F (2017), 'Pengaruh Human Capital (Modal Manusia) Terhadap Pertumbuhan Ekonomi Provinsi Jawa Timur', Jurnal Fakultas Ekonomi dan Bisnis Universitas Brawijaya, pp. 3-11.

Gujarati, D, N, \& Porter (2015), Dasar-dasar Ekonometrika (Edisi 1). Jakarta: Salemba Empat.

Gujarati \& Porter, D. C. (2015), Dasar-Dasar Ekonometrika (Edisi 5). Jakarta: Salemba Empat.

Hussein, U (2004,) Metode Penelitian Untuk Skripsi dan Tesis Bisnis. Jakarta: PT. Raja Grafindo Persada.

Kiaušienè, I (2015), 'Comparative Assessment of Women Unemployment And Poverty In European Union', Intellectual Economics, 9(2), pp. 91-101. doi: 10.1016/j.intele.2015.12.001.

Kuswantoro \& Dewi, I, G, P (2016), 'Analisis Tingkat Pendidikan, PDRB dan Upah Minimum Regional terhadap Kemiskinan Di Provinsi Banten', Jurnal Ekonomi-Qu, 6(1), pp. 18-35.

Mardiyana, L, O, \& Ani, H, M (2019), 'The Effect Of Education And Unemployment On Poverty In East Java Province 2011-2016', IOP Conference Series: Earth and Environmental Science, 243(1), pp. 2011-2016. doi: 10.1088/1755-1315/243/1/012067.

Megawati, E, \& Br Sebayang, L, K (2018), Determinan Kemiskinan di Provinsi Jawa Tengah Tahun 20112014', Economics Development Analysis Journal. Available at: http://journal.unnes.ac.id/sju/index.php/edaj.

Meo, M, S, Kumar, B, Chughtai, S, Khan, V, J., Dost, M. K. Bin, \& Nisar, Q, A (2020), 'Impact Of Unemployment And Governance On Poverty In Pakistan: A Fresh Insight From Non-Linear ARDL Co-Integration Approach', Global Business Review. doi: 10.1177/0972150920920440.

Mohammad Bintang, A, B, \& Woyanti, N (2018), 'Pengaruh Pdrb, Pendidikan, Kesehatan, Dan Pengangguran Terhadap Tingkat Kemiskinan Di Jawa Tengah (2011-2015)', Media Ekonomi dan Manajemen, 33(1), pp. 20-28.

Mohammad, U, F, \& David, J (2019), 'The Relationship between Poverty and Unemployment in Niger State', Signifikan: Jurnal Ilmu Ekonomi, 8(1), pp. 71-78. doi: 10.15408/sjie.v8i1.6725.

Mukthar, S., Saptono, A, \& Arifin, A, S (2019), 'The Analysis Of The Effects Of Human Development Index And Opened Unemployment Levels To The Poverty In Indonesia', Jurnal Ecoplan, 2(2), pp. $77-89$.

Ngozi, B, Gershon, O, Ogundipe, A, Owolabi, O, Ogunrinola, I \& Adediran, O (2020), 'Comparative Investigation of The Growth-Poverty-Inequality Trilemma in Sub-Saharan Africa and Latin American and Caribbean Countries', Journal Heliyon. Elsevier Ltd, 6(11), pp. 1-11. doi: 10.1016/j.heliyon.2020.e05631.

Nisa, K., Wulandari, A, \& Rahayu, R, L.(2020), 'Pengaruh Ketimpangan Pendapatan Terhadap Kemiskinan Di Provinsi Kepulauan Bangka Belitung Tahun 2009-2018', SOROT: Jurnal Ilmu-Ilmu Sosial, 15(April), pp. 55-63.

Olopade, B, C, Okodua, H, Oladosun, M, \& Asaleye, A, J (2019), 'Human Capital and Poverty of Relativity Reduction in OPEC Member-Countries', Jornal Heliyon. Elsevier Ltd, 5(6), pp. 1-7. doi: 10.1016/j.heliyon.2019.e02279.

Omar, A. and Inaba, K, (2020), 'Does Financial Inclusion Reduce Poverty And Income Inequality In Developing Countries? A Panel Data Analysis', Journal of Economic Structures. Springer Berlin Heidelberg, 9(37), pp. 2-25. doi: 10.1186/s40008-020-00214-4.

Prasetyoningrum, A. K. (2018), 'Analisis Pengaruh Indeks Pembangunan Manusia (IPM), Pertumbuhan Ekonomi, Dan Pengangguran Terhadap Kemiskinan Di Indonesia', Equilibrium: Jurnal Ekonomi Syariah, 6(2), p. 217. doi: 10.21043/equilibrium.v6i2.3663.

Putra, I. K. A. A. and Arka, S. (2016), 'Analisis Pengaruh Tingkat Pengangguran Terbuka, Kesempatan Kerja, Dan Tingkat Pendidikan Terhadap Tingkat Kemiskinan Pada Kabupaten / Kota Di Provinsi Bali', EP Unud, 7(3), pp. 416-444.

Sadariawati, R. (2017), 'Pengaruh Human Capital Dan Pertumbuhan Ekonomi Terhadap Kesempatan Kerja Di Sumatera Selatan', Jurnal Ekonomika dan Bisnis, pp. 1-20.

Saddam \& Urimesing, K (2019), 'Analisis Kemiskinan Di Kawasan Timur Indonesia', Jurnal Studi Ekonomi', 13(1).

Safuridar \& Putri, N, I, (2019), 'Pengaruh Indeks Pembangunan Manusia, Pengangguran Dan Jumlah Penduduk Terhadap Tingkat Kemiskinan Di Aceh Bagian Timur', Jurnal Samudra Ekonomika, 3(1), pp. 34-46.

Sayifullah, S \& Gandasari, T, R (2016), 'Pengaruh Indeks Pembangunan Manusia Dan Pengangguran 
Terhadap Kemiskinan Di Provinsi Banten', Jurnal Ekonomi-Qu, 6(2), pp. 236-255.

Sukirno, S (2011), Pengantar Teori Makroekonomi. Jakarta: Rajawali Press.

Sumiyarti (2019), 'Pertumbuhan Ekonomi, Ketimpangan Wilayah Dan Kemiskinan Di Provinsi Banten', Jurnal Media Ekonomi, 26(2), pp. 77-88.

Susanti, S (2013), 'Pengaruh Produk Domestik Regional Bruto, Pengangguran dan Indeks Pembangunan Manusia terhadap Kemiskinan di Jawa Barat dengan Menggunakan Analisis Data Panel', Jurnal Matematika Integratif, 9(1), pp. 1-18.

Syahyuti (2006), Konsep Penting dalam Pembangunan Pedesaan dan Pertanian, Penjelasan Konsep, Istilah, Teori, dan Indikator Serta Variabel. Jakarta: Bina Rena Pariwara.

Todaro, M (2006), Pembangunan Ekonomi. Jakarta: Erlangga.

Todaro \& Smith, M, P (2008), Pembangunan Ekonomi (Edisi Pertama). Jakarta: Erlangga.

Widarjono, A (2007), Ekonometrika Teori dan Aplikasi. Yogyakarta: Ekonisia. FE UII.

Widodo, E., Suriani, E., Putri, I., \& Evi, G (2019), 'Analisis Regresi Panel pada Kasus Kemiskinan di Indonesia', Prosiding Seminar Nasional Penelitian, 2(UNY), pp. 710-717.

Wijayanto, A, T (2016), 'Analisis Keterkaitan Pertumbuhan Ekonomi, Ketimpangan Pendapatan Dan Pengentasan Kemiskinan Di Provinsi Sulawesi Utara Tahun 2000-2010', Jurnal Berkala Ilmiah Efisiensi, 16(02), pp. 418-428.

Yacoub, Y (2013), 'Pengaruh Tingkat Pengangguran Terhadap Tingkat Kemiskinan Kabupaten/Kota Di Provinsi Kalimantan Barat', JIBEKA, 1(8), hh. 176-185. 